\title{
MENYEMAI PENDIDIKAN AGAMA ANTI KONFLIK DAN KEKERASAN DI TENGAH KEHIDUPAN MASYARAKAT MULTIKULTURAL
}

\author{
Bakhrudin Fannani \\ Universitas Islam Negeri Maulana Malik Ibrahim Malang \\ Email : b.fannani@gmail.com \\ Ilham Tohari \\ Institut Agama Islam Negeri Kediri \\ Email : tohariilham@gmail.com \\ Syamsul Arifin \\ Universitas Islam Negeri Malang \\ sy.arifin@ub.ac.id
}

\begin{abstract}
As a multicultural society, Indonesia is face with a big challenge to build a peaceful life. This is based on the assumption that greater diversity will lead to greater conflict potential. Religion as one of the diversity of identities occupies a unique position. On the one hand, religion has the potential to become the root of conflict on the other hand; religion also has great potential in peace building. Therefore, religious education plays an important role in the effort to build the social character oriented towards peace and non-violence. This article discusses in generally the construction of religious education against conflict and violence in plural society. Related to the urgency of religious education in the development of a multicultural society and some of the issues be necessary to considered in the formulation of education against the conflict and violence.
\end{abstract}

Keywords: Religious education, Non Violence, Violence, Multicultural

\begin{abstract}
Abstrak
Sebagai masyarakat yang multicultural, bangsa Indonesia dihadapakan pada tantangan besar untuk membangun kehidupan social yang damai. Hal ini didasarkan pada asumsi bahwa semakin besar keragaman, maka akan semakin besar pula potensi konflik yang akan timbul. Agama sebagai salah satu bentuk keragaman identitas masysrakat menempati posisi yang unik, di satu sisi agama berpotensi untuk menjadi akar konflik disisi lain agama juga mempunyai potensi besar dalam membangun perdamaian. Karena itulah pendidikan agama menempati penanan penting dalam uapaya membangun karakter masyarakat yang berorientasi pada perdamaian dan
\end{abstract}

Nur El-Islam, Volume 5, Nomor 2, Oktober 2018 
nirkekerasan. Artikel ini mendiskusikan secara garis besar kontruksi pendidikan agama antikonflik dan kekerasan dalam kehidupan masyarakat yang plural. Berkaitan dengan urgensi pendidikan agama dalam pembangunan masyarakat multikultural dan juga beberapa pokok masalah yang harus diperhatikan dalam perumusan pendidikan anti konflik dan kekerasan tersebut

Kata kunci : Pendidikan agama, Anti konflik, Kekerasan, Multikultural

\section{A. Pendahuluan}

Indonesia merupakan negara yang kaya dengan berbagai keragaman. Keragaman budaya dan identitas menjadi realitas social yang mencerminkan tatanan masyarakat yang multicultural. Namun akhir-akhir ini bangsa Indonesia menghadapi berbgai massalah yang berakar dari keragaman budaya dan identitas itu. Kontestasi identitas, yang terkadang beriringan dengan kepentingan politik kerap memunculkan berbagai tindakan kekerasan (fisk dan non fisik) dan intoleransi.

Media merkam bagaimana kontestasi identitas tersebut terjadi di berbagai even politik, seperti Pilkada, pileg dan pilpres. Pilkada Jakarta tahun 2017 menjadi salah satu contoh. Berbagai tindakan yang membahayakan tatanan masyarakat multicultural muncul. Mulai dari ujaran kebencian dalam berbagai bentuk, penolakan shalat jenasah untuk pihak yang berbeda pilihan politik, sampai pengusiran dari masjid terhadap sesorang yang dianggap berseberangan identitas politik.

Berbagai konflik dan kekerasan bernuansa SARA juga terjadi sejumlah wilayah lain. Di Bantul, Yogjakarta, seorang camat nonMuslim ditolak masyarakat yang mayoritas muslim. Di kalimantan barat, masyarakat adat Dayak menolak kedatangan seorang tokoh MUI. Pada akhir 2016, Universitas Kristen Duta Wacana (UKDW), Yogyakarta, akhirnya menurunkan baliho iklan kampus yang memuat foto mahasiswi berjilbab, setelah diancam sejumlah orang dari Forum Umat Islam (FUI). Di bulan yang sama, di Bandung sejumlah orang atas nama Pembela Ahlus Sunnah (PAS) Pembubaran kebaktian umat Kristiani. Sedangkan bulan Maret 2017, di Bekasi, sejumlah massa menolak pembangunan gereja. 
Berbagai konflik dan ketegangan antar identitas yang mencederai kebenekaan tersebut, ironisnya, sebagian besar dipicu oleh, atau atas nama, agama. Kenyataan itu menunjukan bahwa masih banyaknya umat beragama yang menjadikan doktrin dan pemahaman keagamaanya sebagai dasar dalam aktifitas-aktifitas kerasan, intoleransi dan teror. Walaupun kelompok-kelompok tersebut tidak bisa diklaim sebagai representasi wajah umat beragama di Indonesia, namun setidaknya hal tersebut menjunjukan bahwa agama berpotensi menjadi ancaman bagi perdamain dan keutuhan bangsa.

Realitas tersebut juga menunjukan bahwa masih banyaknya masyarakat Indonesia yang belum mempunyai kesadaran multikultural. Dengan demikian, bangsa Indonesia, utamanya umat Islam sebagai mayoritas, dihadapkan pada tantangan untuk membumikan ajaran agama sebagai penebar kedamaian dan anti kekerasan. Maka, untuk membumikan pesan damai Agama ditengah masysrakat majemuk tersebut, diperlukan upaya dan langkah-langkah sistematis, pragmatis, integratif dan berkesinambungan. Salah satu langkah yang paling strategis dalam hal ini adalah melalui pendidikan yang diselenggarakan seluruh lembaga pendidikan, baik formal atau non formal.

Pendidikan dipandang sebagai instrumen strategis dalam menanamkan nilai-nilai perdamaian dan berbagai karakter positif yang diperlukan untuk hidup dalam masysrakat yang beragam. Selain karena pendidikan mempunyai peran utama sebagai media transformasi nilai-nilai religi, kebudayaan, pengetahuan, teknologi dan keterampilan, ${ }^{1}$ pendidikan, secara kelembagaan, juga memiliki struktur, sistem dan perangkat yang tersebar di seluruh Indonesia dari daerah sampai pusat, sehingga memungkinkan upaya trasnfer nilai tersebut berlangsung secara masif dan sistematis ${ }^{2}$.

Dengan demikian, pendidikan agama di Indonesia dituntut untuk mengembangkan pola pendidikan berbasis multikultural,

\footnotetext{
${ }^{1}$ Burhanuddin Salam, Pengantar Pedagogik (Dasar-dasar Ilmu Mendidik) (Jakarta: PT. Rineka Cipta, 1996), h. 11.

2 Tim PPK,Modul Pelatihan Program Penguiatan Karakter (Jakarta: Kemendikbud, 2017), h. 3.
} 
inklusivisme, dan pluralis yang pada akhirnya menumbuhkan pemahaman agama yang toleran, welas asih dan berwawasan multikultural. Dalam konteks ini, lembaga pendidikan diposisikan sebagai instrumen pencegahan kekerasan dan penebar kedamaian melalui kegiatan pendidikan yang berorienasi pada upaya membangun kedamaian (peacebuilding) dan menerapkan prinsipprinsip anti kekerasan.

Artikel ini hadir untuk memberi sumbangsih upaya pengembangan pola pendidikan agama yang diharapkan dapat menambah alternative gagasan untuk membangun rumusan pendidikan yang damai, anti kekrasan dan beroriantasi multikultural.

\section{B. Konflik, kekerasan dan keragaman; sebuah penghampiran konseptual}

Kata konflik dalam Kamus Besar Bahasa Indonesia diartikan sebagai percekcokan, perselisihan; pertentangan. ${ }^{3}$ Dalam pandangan Webster, pengertian konflik mengalami perluasan makna, dari yang semula merujuk pada sebuah konfrontasi dalam bentuk fisik, seperti perkelahian atau peperangan, menjadi konfrontasi dalam berbagai bentuk seperti "ketidaksepakatan yang tajam atau oposisi atas berbagai kepentingan, ide, dan lain-lain". ${ }^{4}$ Sejalan dengan pengertian tersebut, Winardi mendefinisikan konflik sebagai suatu pertentangan atau ketidakcocokan pendapat yang kuat dalam hal kepentingan atau pemikiran yang terjadi antara orang orang, kelompok kelompok, atau organisasi organisasi. ${ }^{5}$

Dalam konteks sosial, konflik dapat maknai sebagai benturan kekuatan dan kepentingan antara satu kelompok dengan kelompok lain dalam proses perebutan sumber sumber kemasyarakatan baik

\footnotetext{
3 Depertemen Pendidikan dan kebudayaan, Kamus Besar Bahasa Indonesia.http://kbbi.web.id/konflik.

${ }^{4}$ Dean G. Pruitt \& Jeffrey Z. Rubin, Social Conflict: Escalation, Stalemate, and Settlement, terj. Teori Konflik Sosial (Yogyakarta: Pustaka Pelajar, 2004), h. 9.

${ }^{5}$ Winardi, Manajemen Konflik: Konflik Perubahan dan Pengembangan (Bandung: Mandar Maju, 1994), h. 1.
} 
ekonomi, politik,sosial dan budaya yang relatif terbatas. ${ }^{6}$ Adanya benturan kepentingan antar kelompok tersebut bisa dipahami sebagai kontestasi identitas dalam ruang sosial. Kontestasi tersebut adalah konsekuensi logis dari adanya keragaman atau kemajemukan. Sehingga wajar bila para sosiolog seolah sepakat bahwa keragaman atau kemajemukan dalam ruang sosial merupakan sumber penyebab terjadinya konflik.

M Setiadi misalnya, mengemukan dua penyebab konflik, yaitu kemajemukan horizontal dan kemajemukan virtikal.Kemajemukan horizontal artinya adalah keragaman secara kultural, seperti suku bangsa, agama, ras.Juga keragaman dalam arti perbedaan pekerjaan dan profesi seperti petani, buruh, pedagang, pengusaha, pegawai negeri, militer, wartawan, alim ulama, sopir dan cendekiawan.Kemajemukan horizontal-kultural menimbulkankonflik yang masing-masing unsur kultural tersebut mempunyai karakteristik sendiri dan masing-masing penghayat budaya tersebut ingin mempertahankan karakteristik budayanya tersebut.

Sedangkan kemajemukan vetikal merujuk pada keragaman masyarakat yang terpolarisasi berdasarkan kekayaan, pendidikan, dan kekuasaan. Kemajemukan vertikal dapat menimbulkan konflik sosial kerena ada sekelompok kecil masyarakat yang memiliki kekayaan, pendidikan yang mapan, kekuasaan dan kewenangan yang besar, sementara sebagian besar tidak atau kurang memiliki kekayaan,pendidikan rendah, dan tidak memiliki kekuasaan dan kewenangan. Pembagian masyarakat seperti ini merupakan benih subur bagi timbulnya konflik sosial. ${ }^{7}$

Pararel dengan diskripsi diatas, Bagong Suyanto ${ }^{8}$ mengidentifikasi tiga penyebab konflik, yang ketiganya juga

\footnotetext{
${ }^{6}$ Robert lawang, Buku Materi Pokok Pengantar Sosiologi (Jakarta:universitas terbuka,1994), h. 53.

${ }^{7}$ Elly M. Setiadi dan Usman Kolip, Pengantar Sosiologi Pemahaman Fakta dan Gejala Permasalahan Sosial: Teori, Aplikasi, dan Pemecahannya (Jakarta : Kencana, 2011), h. 361.

${ }^{8}$ J. Dwi Narwoko dan Bagong Suyanto, Sosiologi Teks Pengantar dan Terapan (Jakarta: Kencana, 2005), h. 68.
} 
bermuara pada perbedaan dan keragaman. Pertama, perbedaan pendirian dan keyakinan. Perbedaan ini terjadi dalam level individu. Dalam realitas sosial tidak ada satu pun individu yang memiliki karakter yang sama sehingga perbedaan pendapat, tujuan, keinginan tersebutlah yang mempengaruhi timbulnya konflik sosial.

Kedua perbedaan kebudayaan. Perbedaan kebudayaan akan menibulkan konflik antar kelompok. Selain itu, perbedaan kebudayaanakan mengakibatkan adanya sikap etnosentrisme yaitu sikap yang ditunjukkan kepada kelompok lain bahwa kelompoknya adalah yang paling baik. Jika masing-masing kelompok yang ada di dalam kehidupan sosial sama-sama memiliki sikap demikian, maka sikap ini akan memicu timbulnya konflik antar penganut kebudayaan.

Ketiga, perbedaan kepentingan. Perbedaan kepentingan berkaitan dengan tujuan masing-masing kelompok sosial yang berbeda-beda, kelompok-kelompok itu akan bersaing dan berkonflik untuk memperebutkan kesempatan dan sarana.

Sedangkan konsep kekerasan, dalam kajian social juga bertalian dengan konsep konflik. Karena dalam skala tertentu, konflik cenderung disertai dengan kekerasan. ${ }^{9}$ Kekerasan merupakan pertanda tidak dapat diatasinya akar konflik sehingga menimbulkan kekerasan dari model kekerasan yang terkecil hingga peperangan.

Mattew, seperti dikutip Bashori, mendiskripsikan perilaku kekerasan dengan istilah agresi, yaitu untuk menggambarkan perilaku destruktif yang sulit dikontrol, tidak hanya meliputi tindakan yang bersifat fisik, melainkan juga mencakup kekerasan verbal, psikologis dan simbolis, atau kombinasi dari berbagai aspek tersebut. ${ }^{10}$

Kekerasan memang identik dengan prilaku yang destruktif dan negative, namun demikian bukan berarti kekerasan multak harus ditinggalkan. Kekerasan dibenarkan dalam kondisi tertentu. Karena itulah Hassan Hanafi membuat dua kategori kekerasan, yaitu opposite

\footnotetext{
${ }^{9}$ Soerjono Soekanto, Sosiologi Suatu Pengantar (Jakarta: Rajawali Pers, 1992), h. 86.

${ }^{10}$ Bashori A. Hakim dalam Badan Litbang dan Diklat Kementerian Agama, Pandangan Masyarakat Terhadap Tindak Kekerasan Atas Nama Agama (Jakarta : Maloho Jaya Abadi Press, 2010), h. 12.
} 
violence (kekerasan yang menindas) dan revolutionary violence (kekerasan revolusioner).

Oppressive violence adalah kekerasan politik yang dilakukan suatu rezim yang sedang berkuasa untuk melakukan ketidakadilan sosial dan mempertahankan status-quo.Sedangkan revolutionary violence adalah bentuk pertahanan diri yang dilakukan rakyat dalam kapasitasnya menentang ketidakadilan sosial dan tekanan militer. Oppressive violence dipahami sebagai kekerasan yang menekan sedangkan revolutionary violence adalah kekerasan yang membebaskan. Kekerasan yang pertama adalah murni penyerangan sedangkan kekerasan yang kedua adalah upaya pertahanan diri. Yang pertama dilakukan oleh rezim penindas dan dictator yang berkekuatan besar, sementara yang kedua dilakukan oleh rakyat yang termobilisasi oleh gerakan pembebasan, front nasional, dan kelompok revolusioner. ${ }^{11}$ Dari konsepsi ini dapat dipahami bahwa penggunaan kekerasan dibenarkan dalam konteks mempertahankan diri atau dalam upaya untuk membebaskan dari kedzaliman atau ketidakadilan.

\section{Agama dan Konflik; hubungan sarat ambiguitas}

Hubungan Agama dan konflik adalah hubungan yang ditandai ambiguitas. Hubungan itu juga dapat dianalogikan sebagai koin dengan dua sisi yang tak terpisahkan, disatu sisi agama dipercaya sebagai pembawa perdamaian. Namun di sisi lain, agama juga merupakan salah pemancing terjadinya konflik dan kekerasan. ${ }^{12}$

Galtung bahkan mengidentifikasi bahwa agama sebagai kenyataan sosial mempunyai spektrum yang luas sebagai pemicu kekerasan. Galtung mengklasifikasikan kekerasan dalam tiga tipe, yaitu kekerasan langsung, kekerasan struktural, dan kekerasan budaya; dan agama masuk kedalam semua tipe kekerasan itu. Dalam kontek ini Galtung mengungkapkan bahwa agama berperan sebagai domain basis munculnya kekerasan kultural dan berfungsi sebagai

\footnotetext{
${ }^{11}$ Hassan Hanafi, Agama, Kekerasan dan Islam Kontemporer, terj. Ahmad Najib, (Yogyakarta: Jemdela, 2001), h. 53-54.

${ }^{12}$ Rizal Panggabean dan Ihsan Ali Fauzi, Merawat Kebersamaan;Polisi,Kebebbasan Beragama dan Perdamaian (Jakarta :Yayasan Abad Demokrasi), h.155.
} 
legitimator kekerasan. Agama dalam perannya dalam kekerasan budaya memmpunyai kekuatan untuk melegitimasi kekerasan, baik struktural maupun kekerasan langsung, hingga kekerasan itu mendapat penerimaan dalam kognisi masyarakat, atau menjadi hal yang dimaklumi. ${ }^{13}$

Peran agama ini, sebagai pemicu kekerasan dan juga perdamamian, dapat dipahami dengan perspektif Webber. Webber mengemukakan bahwa prilaku suatu kelompok social disadari atas komitmennya pada system kepercayaan tertentu, yang juga menjadi asal tujuan, standar perilaku dan legitimasi kekuasaan. ${ }^{14}$ Clifford Geertz menyebut peran agama ini sebagai "sumber makna dan kebijakan" (a source of meaning and wisdom) yang diyakini berasal dari "hakikat realitas yang fundamental" sehingga pemeluknya mempunyai "vitalitas moral", yaitu kekuatan penggerak dalam aksiaksi kemanuasiaan. Selin itu, agama juga menyediakan ajaran, doktrin, berbagai symbol yang digunakan sebagi kaca mata untuk menkar segala sesuatu dengan standart tertentu (common values), misalnya baik-buruk atau benar-salah ${ }^{15}$.

Dari sinilah kemudian berbagai perbedaan timbul. Karena tiap agama atau kepercayaan merupakan "sumber makna" yang berbeda, yang tentu saja memunculkan berbagai pemahaman yang berbeda. Maka, konflik sosial dan tindak kekerasan "atas nama Tuhan”, atau "atas nama Agama” tidak dapat dihindari manakala agama melalui teks-teks keagamaan secara implisit atau eksplisit mengajarkan nilainilai eksklusifisme, fanatisme, keunggulan doktrin, dan truth claim. ${ }^{16}$

Sungguhpun demikian, agama juga mempunyai potensi besar sebagai penebar kedamaian. Ajaran untuk menciptakan kedamaian

\footnotetext{
${ }^{13}$ Johan Galtung, Kekerasan Budaya, dalam Thomas Santoso (ed.), Teori-teori kekerasan (Jakarta: Ghalia Indonesia \& Universitas Kristen Petra, 2002), h. 187-188.

${ }^{14}$ H. H. Gerth \& C. Wright Mills, From Marx Weber: Essays in Sociology (London: Routledge, 1991), h. 272-276.

${ }^{15}$ Sumanto al Qurtuby, Pluralisme, Dialog dan Piecbuilding berbasis agama di Indonesia, dalam Elza Peldi Taher (ed), Merayakan kebebasan beragama; bunga Rampai menyambut 70 tahun Djohan Effendi (Jakarta Yayasan Abad demokrasi, 2011) h. 178-179.

${ }^{16}$ Sumanto al Qurtuby, Jihad Melawan Ekstremis Agama Membangkitkan Islam Progresif (Jakarta: PT. Borobudur Indonesia Publishing, 2009), h. 27.
} 
dan ketenangan ada di semua agama. Dalam ajaran agama Hindu misalnya, ada doktrin ahimsa. Secara etimologi, ahimsa yang dapat diterjemahkan dengan tanpa kekerasan (non-violence), atau perdamaian (peace). Non injury ini bersifat universal, bagi semua mahluk hidup termasuk manusia. Ahimsa juga disebut sebagai altruistic faith. Ajaran ini berasal dari Jainisme yang disebut-sebut oleh George kotturan sebagai salah satu agama tertua di dunia. Dalam konteks interaksi sosial, prinsip Ahimsa ini bersumber pada suatu ketakinan bahwa seluruh manusia adalah bersaudara, dari manapun asalnya, siapapun dia, dan apapun ras, suku, negara dan agamanya. ${ }^{17}$

Budhisme juga kaya akan prinsip perdamaian. Salah satunya konsep panatipata veramani dan panatipata pativirati. Dua kalimat ini mengandung arti yang sama, yaitu menjauhi bentuk kekerasan atau apapun yang dapat menyebabkan mahluk hidup terluka. kedua term tersebut berhubungan dengan ajaran sila dan vinaya yang juga bermakna menolak membunuh dan melukai sesama makhluk. ${ }^{18}$ Dalam interaksi sosial ada lima ajaran dasar menurut Budha yang menjadi pedoman: “ tidak membunuh; tidak mencuri (merampok); tidak berdusta; tidak terlibat dalam perzinaan; dan jangan minum yang memabukan". Kelima prinsip ini menjadi dasar untuk membangun kehidupan damai dalam ajaran Budda. ${ }^{19}$

Sedangkan Kristen memiliki ajaran "Gospel of Love". Dalam Matthew, Jesus mengatakan "Kasihanilah musuhmu dan berdoalah bagi mereka yang menganiayamu" (Matthew, 5/44). Dalam narasi lain juga disebutkan, “ jika seseorang memukul pipimu, balaslah dengan cara yang lain” (Luke, 6/29). Di dalam bagian New Testament (Kitab

17 Aunur rofiq, Tafsir Resolusi Konflik (Malang: UIN Maliki Press, 2011), h. 62.

${ }^{18}$ Lihat GP. Malalasekera, O.b.e Encyclopedia of Buddhism, (Colombo: The Cultural Publication Co. Ltd, 1984), h. 287; untuk pembahasan lebih luas tentang ahimsa lihat pula George kotturan dalam Aunur Rofiq Tafsir Resolusi Konflik (Malang: UIN Maliki Press, 2011)

${ }^{19}$ George Kotturan, dalam Aunur Rofiq, Tafsir Resolusi Konflik, h. 64. 
Pejanjian Baru), tidak ada ajaran yang memberikan legitimasi kebenaran terhadap tindak kekerasan beragama. ${ }^{20}$

Dalam ajaran Islam, ajaran perdamaian terdapat salah satunya dalam konsep rahmatan lil'alami, yang berarti bahwa Islam adalah pembawa rahmat bagi seluruh umat manusia dan seluruh alam. Nama "Islam" sendiri juga berarti keselamatan atau kedamaian. Dalam konteks ini Abu Nimer menegemukakan bahwa pesan utama Islam adalah kedamaian, dan bahwa berbagai perangkat nilai-nilai dan keyakinan dalam Islam seharusnya merupakan pondasi untuk mencapai kesucian hidup manusia, keadilan ('adala), kesetaraan (Musawwa), kasih saying (Rahma), perbuatan baik ('amal al khair) dan solidaritas. ${ }^{21}$

Dengan demikian, tidak ada satupun agama tersebut yang mengajarkan umatnya untuk meakukan tindak kekerasan dalam beragama, sehingga tindak kekeraan atas nama agama, menjadi tanggung jawab semua penganut agama, baik dalam konteks individu, kelompok maupun negara.

\section{Urgensi Pendidikan agama anti konflik dan kekerasan dalam} bingkai masyarakat multikultural

Pendidikan, dalam Pendidikan dalam Undang-Undang Sisdiknas, dirumuskan sebagai usaha yang sitematis untuk mengembangkan potensi peserta didik untuk memiliki kekuatan spiritual keagamaan, pengendalian diri, kepribadian, kecerdasan akhlak mulia, serta keterampilan yang dibutuhkan dirinya dan masyarakat, bangsa, dan negara. ${ }^{22}$

\footnotetext{
${ }^{20}$ Departemen Agama, Pedoman Pembinaan Kerukunan Hidup Beragama: PokokPokok Ajaran Agama Tentang Kerukunan Hidup Bersama (Jakarta: Departemen Agama, 1990), h. 30.

${ }^{21}$ Mohammed Abu Nimer dan Ilham Nasser, Building Peace Education In The Islamic Educational Context, International Review of Education, April 2017, Volume 63, Issue 2, hal 160. DOI: 10.1007/s11159-017-9632-7.

${ }^{22}$ Undang Undang no 20 tahun 2003tentang pendidikan nasional Bab 1 ketentuan Umum pasal 1 ayat 1.
} 
Dari rumusan diatas dapat dilihat bahwa pemahaman bahwa pendidkan adalah sebuah proses transformatif, mengembangkan potensi manusia sehingga menjadi pribadi yang berguna bagi lingkunganya. Oleh karena itu, dalam prosesnya, pendidikan merupakan upaya pengembangan potensi-potensi manusia baik itu potensi fisik, potensi cipta, rasa maupun karsanya, agar potensi itu menjadi nyata dan dapat berfungsi dalam perjalanan hidupnya ${ }^{23}$.

Dari konsepsi itu juga dapat dipahami bahwa pendidikan tidak terbatas oleh isntrumen, kurikulum, atau metodologi tertentu. Namun pendidikan, seperti halnya proses belajar, dapat dilakukan melalui berbagai instrumen, cara, dan waktu yang tak terbatas. Pada intinya, proses pendidikan dapat dilakukan di berbagai tempat dan cara,baik formal maupun non formal. ${ }^{24}$

Sedangkan pendidikan anti kekerasan secara definitif sebangun dengan konsep pendidikan perdamaian (peace education), yang dirumuskan sebagai proses perolehan nilai (value), pengetahuan (knowledge) dan pengembangan sikap (developing attitude), keterampilan (skill), dan perilaku untuk hidup harmonis dengan diri sendiri dari segi psikologis (developing psychological), dengan orang lain, dan dengan lingkungan alam (nature). Perserikatan BangsaBangsa (PBB) telah mendeklarasikan, akan pentingnya pendidikan perdamaian. ${ }^{25}$

Dalam konteks proses pembelajaran, konsep pendidikan anti kekerasan dimaknai sebagai pendidikan yang menolak adanya kekerasan dalam proses pembelajaranya. Assegaf, menjelaskan bahwa pendidikan anti kekerasan merupakan pendidikan yang tercipta

\footnotetext{
${ }^{23}$ Syaiful Sagala, Manajemen Stratejik dalam Peningkatan Mutu Pendidikan (Bandung: Alfabeta, 2007), h. 7.

${ }^{24}$ George R. Knight, Filsafat Pendidikan (Yogyakarta: Gama Media, 2007), h. 16

25 James S. Page, Peace Education: Exploring Ethical and Philosophical Foundations, Chapter 1, (Charlotte: Information Age Publishing, 2008) dan Page, James S. 'Chapter 9: The United Nations and Peace Education'. dalam : Monisha Bajaj (ed.) Encyclopedia of Peace Education (Charlotte: Information Age Publishing, 2008), h. 75-83.
} 
dengan damai, aman, dan tenteram serta melindungi segenap civitas yang berada dalam rung lingkup pendidikan tersebut. ${ }^{26}$

Dengan demikian secara garis besar pendidikan anti kekerasan dimaksudkan sebagai pendidikan yang diorientasikan untuk membentuk karakter masyarakat yang damai, aman, dan tenteram dan berwawan multicultural, yang dilakukan dengan proses pembelajaran yang aman, damai, tentram dan menghindari tindak kekerasan. Dalam konteks ini, agama menempati peran sebagai dasar dan sumber nilai dalam melaksanakan membentuk karekater masyarakat tersebut. Karena itu, pendidikan agama juga dapat dimaknai sebagai proses atau usaha internalisasi ajaran agama yang beroreintasi pada penciptaan kehisupan bermasyrakat yang damai dengan menghindari konflik dan tindak kekerasan yang distruktif.

Peran pendidikan agama dalam pembangunan kehidupan pluralistic yang damai menjadi penting, mengingat selama ini orientasi kearah itu cenderung diabaikan. Pendidikan agama, terutama di sekolah, lebih besar ditekankan kepada aspek pengetahuan mengenai ajaran agama. Peserta didik (siswa) dianggap telah berhasil dalam pendidikan agama jika ia dianggap telah menguasai sejumlah bahan pelajaran dan mampu menjawab soal-soal jawaban berkaitan dengan ajaran agama.

Sejauh mana internalisasi pengetahuan dan nilai-nilai ajaran agama dalam prilaku kehidupan keseharin kurang mendapat perhatian. Seperti sejauhmana penerapan kedisiplinan dalam beribadah, berkepribadian luhur, sopan santun, saling menghormati dan menghargai, suka menolang, jujur, sabar, dan lain sebaginya.

Kecenderungan lain adalah alphanya pendidikan agama dalam menanamkan sikap dan prilaku yang sesuai dengan bingkai hidup bersama dalam keragaman (multikultural). Ini berarti bahwa, pendidkan agama tidak memberikan perhatian lebih kepada bagaimana cara untuk dapat berdampingan dengan orang lain yang berbeda etnis,budaya dan agama.

\footnotetext{
${ }^{26}$ Abdurrahman Assegaf, Pendidikan Tanpa Kekerasan:Tipologi,Kondisi,Kasus dan Konsep (Yogyakarta: Tiara Wacana, 2004)
} 
Idealnya, pendidikan agama diarahkan untuk menjadikan anak didik memiliki pemahaman dan perilaku religius yang berjalan paralel dengan kemampuan mereka untuk dapat hidup bersama orang lain yang berbeda etnik, budaya dan agama. Sehingga peserta didik tidak hanya mempenyai pengetahuan mengenai ajaran agama,tapi juga mempunyai sikap kepekaan soaial,toleransi,empati terhadap orang lain, tidak apatis terhadap keyakinan agama lain, dan lain sebagainya ${ }^{27}$

Tidak adanya penekanan terhadap penanaman nilai nilai dan sikap yang dibutuhkan untuk hidup bersama dalam ruang sosial yang multikultural, pada giliranya akan menimbulkan sikap intoleran terhadap agama atau kelompok lain. Amin Abdullah mengidentifikasi bahwa sikap intoleran dikalangan umat beragama memang tidak bisa dilepaskan dari peran pendidikan agama. Sikap intoleran itu dipicu oleh pelajaran agama yang lebih menitikberatkan pada pendekatan normatif yang berdimensikan 'salah atau benar' semata-mata, bukan pada dimensi eksoteris yang bersifat historis dan sosiologis. Hal tersebut pada taraf tertentu kerap menimbulkan ketegangan, baik secara internal maupun hubungan antar agama. Sayangnya, pendekatan model tersebut masih dominan dalam pelajaran agama di negeri ini, mulai dasar sampai tingkat perguruan tinggi. Sehingga wajar bila dalam konteks kemajemukan, perbedaan agama, lebih banyak menjadi bagian dari persoalan atau pemicu konflik, daripada sebagai bagian dari solusi konflik.28

Pendidikan agama, dengan demikian, mempunyai tugas besar dalam upaya menjadikan agama sebagai solusi dalam mengatasi konflik dan menciptakan kedamaian dalam masysrakat yang majemuk. Dalam konteks Indonesia, nilai keberagamaan yang penting untuk dikembangkan melalui pendidikan agama adalah nilai-nilai persaudaraan, toleransi, multikulturalisme dan perdamaian. Penanaman nilai-nilai toleransi memungkinkan peserta didik

\footnotetext{
27. Kamrani Buseri, Antologi Pendidikan Islam dan Dakwah: Pemikiran Teoritis Praktis Kontemporer (Yogyakarta: UII Press, 2003), h. 27

${ }^{28}$ Amin Abdullah, Agama dan Pembentukan Kepribadian Bangsa di Indonesia, https://aminabd.wordpress.com/2010/06/03/71/. Diakses 6 November 2018
} 
memiliki pemahaman dan perilaku religius yang berjalan paralel dengan kemampuan mereka untuk dapat hidup bersama orang lain yang berbeda etnik, budaya dan agama (to live together). Kemajemukan (pluralism) bangsa Indonesia juga harus menjadi pedoman dalam membingkai sebuah kehidupan yang mengedepankan semangat persahabatan dan persaudaraan demi tegaknya nilai-nilai demokrasi dan kebangsaan. ${ }^{29}$

Pendidikan agama, dengan demikian, mempunyai tugas besar dalam upaya menjadikan agama sebagai solusi dalam mengatasi konflik dan menciptakan kedamaian dalam masysrakat yang majemuk.

\section{E. konstruksi pendidikan agama anti konflik dan kekrasan; tawaran garis besar}

Dari pemaparan diatas dapat dipahami bahwa pendidikan agama secara garis besar merupakan sarana untuk menanamkan nilainilai perdamaian. Nilai-nilai tersebut tentu haruslah bersumber dari doktrin teologis agama tersebut. Hal ini tidaklah sulit, karena semua agama pasti mempunyai ajaran perdamaian, yang secara singkat telah dipaparkan di atas.

Demkian konteks Islam, pendidikan anti kekerasan dapat dikembangkan dengan berpedoman pada nilai-nilai perdamaian yang dapat diimplementasikan dalam membentuk karekter individu seorang muslim. Munir Mulkan, menerangkan beberapa nilai dalam Islam yang harus dikembangkan dalam kehidupan masyarakat. Nilai-nilai tersebut anatara meliputi persaudaraan (ukhuwah islamiyah), perdamaian (islah), kasih sayang (rahmat), kebaikan (ihsan), toleransi (tasamuh), dan pema'af (afwan). ${ }^{30}$

Baidawy juga menawarkan 17 nilai yang dapat menjadi menjadi dasar untuk mengembangkan pendidikan perdamaian berbasis Islam.

${ }^{29}$ Mohammad Takdir Ilahi, Nasionalisme dalam Bingkai Pluralitas Bangsa: Paradigma Pembangunan dan Kemandirian Bangsa (Yogyakarta: Ar-Ruzz Media, 2012), h. 33.

30 Abdul Munir Mulkhan, Paradigma Intelektual Muslim; Pengantar Filsafat Pendidikan Islam dan Dakwah (Yogyakarta: Sippress, 1993), h. 30. 
Nilai-nilai itu terbagi dalam tiga ketegori, yaitu nilai inti, implementasi, dan tujuan. ${ }^{31}$

Nilai inti berisi empat konsep yaitu, Tawhid, Ummah, Rahma, al-Musawwah. Tawhid dalam konteks ini berarti meyakini keesaan Allah, sekaligus juga menyadari bahwa segala sesuatu bersumber dari Allah. Kesadaran ini pada tahap selanjutnya mengarah pada kesatuan umat manusia. Bahwa semua manusia pada dasarnya adalah saudara (ukhuwwah basyariyyah) karena sama-sama bersumber (diciptakan) Allah. Ummah (hidup bersama) berarti setiap orang memiliki akses yang sama untuk menjadi penghuni alam semesta ini, hidup berdampingan, dan mengikat ikatan sosial dalam kelompok, komunitas, dan masyarakat. Sedangkan konsep Rahma (kasih sayang) merupakan manifestasi sifat Allah, dengan demikian manusia diciptakan oleh Tuhan untuk berinteraksi dan berkomunikasi satu sama lain berdasarkan semangat cinta dan perhatian. Nilai inti terkhir adalah Al-musawah, (egalitarianisme). Ini berarti semua manusia adalah saudara dan setara di hadapan Allah meskipun jenis kelamin, jenis kelamin, ras, warna kulit, dan agama mereka berbeda.

Kategori kedua adalah nilai, atau konsep-konsep yang masuk dalam tataran implementasi, yaitu, Ta'aruf, Ihsan yang berarti kesadaran untuk hidup bersama dengan yang lain dengan berkolaborasi dan saling memberi dan menerima. Tafahhum (saling pengertian), Takrim (saling menghormati), Fastabiqul Khairat (berlomba dalam kebaikan), Amanah (saling percaya), Husnuzhan (berprasangka baik), Tasamuh (toleransi) yang juga berarti menghargai keragaman dan perbedaan agama, etnis dan budaya. Konsep lainya adalah 'Afw dan Magfirah yang berarti memaafkan dan melupakan semua bentuk penyiksaan, kejahatan, dan kesalahan yang dilakukan oleh seseorang. Terakhir adalah Sulh (rekonsiliasi) dan Islah (resolusi konflik).

${ }^{31}$ Zakiyuddi Baidhawy, Building Harmony and Peace through Multiculturalist Theology-based Religious Education: an Alternative for Contemporary Indonesia, British Journal of Religious Education, Volume 29, Number 1 (January 2007), h. 15-30. DOI: 10.1080/01416200601037478 
Sedangkan nilai-nilai yang masuk dalam kategori tujuan adalah salam, lyn dan 'adl. Silah atau salam bermakna kedamaian, jadi termasuk dalam konsep ini adalah setiap usaha untuk membangun perdamaian, dan memeliharanya. Lyn (lemah lembut) dimaknai sebagai budaya non kekerasan, sehingga mencakup semua tindakan, ucapan, sikap, perilaku, berbagai struktur dan sistem yang melestarikan dan melindungi keamanan dan keselamatan fisik, mental, sosial, dan lingkungan. Terakhir, 'adl (keadilan), berarti kesetimbangan sosial, moderat dalam menanggapi perbedaan, dan keadilan dan keterbukaan dalam mengenai berbagai sudut pandang dan tindakan.

Dalam usaha mengembangkan nilai nilai perdaamaian dan nirkekerasan melalui institusi sekolah ada beberapa pokok persoalan yang harus diperhatikan dan dikembangkan, yaitu:

1. Pengembangan Kurikulum yang berorientasi kepada pembentukan karakter dan keterampilan hidup bersama.

Kurikulum pendidikan dalam sekolah di Indonesia dinilai banyak kalangan kurang memperhatikan penanaman nilai atau karakter yang akan mengantarkan peserta didik menjadi pribadi yang berahlak mulia. Dengan kata lain, fokus pendidikan hanya untuk mengembangkan kemampuan kognitif siswa, sehingga sekolah lebih banyak mencetak siswa yang cerdas namun kurang dalam mencetak siswa yang berkarakter atau berahlak mulia. Dari sinilah maka kurikulum sekolah harus dikembangkan dengan orientasi penanaman nilai atau karakter siswa atau peserta didik.

Kurukulum pendidikan agama dengan demikian juga harus berorientasi pada pembentukan karakter tersebut. Agama menyediakan nilai-nilai utama dalam membentuk karakter siswa . Selanjutnya pemahaman keimanan tersebut dikoneksikan dengan dengan nilai-nilai yang seharusnya diaplikasikan dalam kehidupan bermasyarakat yang majemuk, seperti ajaran tentang perdamaian dan penghargaan kepada "yang lain " yang "yang berbeda” (the others).

2. Adobsi kearifan local dalam pengembangan karakter siswa.

Internalisasi nilai nilai bina damai atau harmoni dalam kurikulum pendidikan agama di sekolah seyogyanya juga 
mempertimbangkan faktor kearafan lokal, sehingga dapat dengan mudah diterima masyarakat. Indonesia dengan beragam budayanya juga sangat kaya dengan berbagai nilai-nilai lokal yang secara subtansial selaras dengan nilai-nilai agama dan mendukung karakter yang diperlukan dalam kehidupan multicultural.

Salah satu contoh, adalah konsep pendidikan "Harmoni" yang dikemabangkan oleh Wahana Visi Indonesia di wilayah Sulawesi Tengah dan Maluku Utara, secara khusus di kota Palu dan kabupaten Poso. Konsep pendidikan Harmoni dilakukan dengan mengembangkan tiga aspek utama yaitu Harmoni Diri, Harmoni Sesama dan Harmoni Alam. Harmoni diri merepresentasikan nilainilai utama keyakinan (iman), tanggungjawab dan percaya. Harmoni sesama berkorelasi dengan nilai peduli, jujur, dan menghargai sesama. Dan harmoni alam merepesentasikan kecintaan dan pemeliharaan terhadap lingkungan.

Hal yang sama juga dilakukan oleh Peace Generation, yang telah mengeluarkan modul training perdamaian kepada guru-guru dan aktivis perdamaian serta mahasiswa agar dapat diterapkan kepada anak didik di sekolah maupun di lembaga keagamaan. Modul ini berisi konsep dan strategi pengembangan 12 nilai yang perdamaian . Nilai yang dimaksud adalah (1) menerima diri, (2) mengatasi prasangka, (3) Perbedaan Etnis, (4) Perbedaan Agama, (5) Perbedaan Jenis Kelamin, (6) Perbedaan status ekonomi, (7) perbedaan kelompok atau geng, (8) keanekaragaman, (9) konflik, (10) menolak kekerasan, (11) mengakui kesalahan, dan (12) memberi maaf. ${ }^{32}$

Kendati beberpa konsep pengembangan kurikulum berorientasi perdamakian tersebut tidak secara langsung bersumber dari agama, namun secara subtansial nilai nilai tersebut sesua dengan ajaran agama. Dengan demikian konsep tersebut dapat dijadikan rujukan dalam pengembangan kurikulum pendidikan agama disekolah.

\section{Pengembangan materi yurispundensi inklusif.}

${ }^{32}$ Erik Lincoln dan Irfan Amalee, Peace Generation: 12 Nilai Perdamaian (Bandung: Penerbit Pelagi Mizan, 2006) dan Erik Lincoln dan Florence Farida, Peace Generation: 12 Nilai Perdamaian, edisi Kristen (Bandung: Penerbit satu-satu, 2011) 
Materi Pengajaran Ajaran agama tentu tidak bisa meninggalkan aspek pengetahuan tentang agama. Ini terkait dengan berbagai ajaran yang berhubungan dengan berbagai doktrin teologis dan juga ajaran mengenai bidang hukum. Seperti dalam dalam Islam, terdapat banyak sekali perbedaan dalam bidang yurispudensi (fiqh), misalnya soal tata cara beribadah. Walaupun banyak intelektual berpendapat bahwa fiqh bukan merupakan ajaran fundamental agama melainkan hanya masalah cabang (furu') namun dalam kenyataanya perbedaan dalam Fiqh ini kerap memicu konflik.

Dengan demikian konstruksi materi dan kurikulum pendidikan agama selain mengajarkan nilai-nilai yang selaras dengan perdamaian yang hidup bersama, sepatutnya juga dibangun dengan memberi pemahaman kepada siswa mengenai kekayaan pandangan dalam fiqh dan cara menyikapi keragaman pandangan tersebut. Sehingga siswa mempunyai pemahamaan yang inklusif dan tidak gampang menyalahkan pemahaman pihak lain.

4. Mengawal inklusifisme dan pandangan moderat dalam Bahan ajar (modul)

Pada tahun 2016 PPIM melakukan riset yang menyoroti muatan radikalisme, intoleransi dan kekerasan dalam buku teks PAI SD-SMA. Hasilnya, riset ini menyatakan bahwa buku PAI SDSMA mengandung muatan radikalisme dan intoleransi. Kesan intoleransi pada buku teks PAI tercermin dalam bentuk teks yang sering menyalahkan pendapat atau praktik ibadah yang berbeda, mempromosikan pendapat yang satu tanpa menghadirkan pendapat yang lain. ${ }^{33}$ Selain itu juga ditemukan muatan dalam buku ajar (buku ajar dan LKS) yang yang mengajak siswa-siswi untuk bersikap antiBarat, intoleran, fanatik, anti demokrasi di samping muatan toleransi dan demokrasi. ${ }^{34}$ Konsep yang saling bertentangan ini tentu akan menimbulkan masalah dan kebingungan bagi peserta didik.

\footnotetext{
${ }^{33}$ Pusat Pengkajian Islam dan Masysrakat UIN Jakarta, Policy Brief; Tanggung Jawab Negara dalam Pendidikan Agama Islam, September 2016.

${ }^{34}$ Abu Rokhmad, Radikalisme Islam dan Upaya Deradikalisasi Paham Radikal. Jurnal Walisongo, Vol. 20, No. 1, (Mei 2012): h. 79-114.
} 
Karena itu dapat diambil pelajaran bahwa penting untuk benarbenar memperhatikan muatan buku ajar agama. Muatan buku ajar harus sesuai dengan orientasi kurukulum berbasis perdamaian, supaya penyebaran pemahaman yang tidak kompatible dengan multikulturalisme dapat dicegah.

5. Kualitas Pengajar (guru) dan tokoh agama

Kualifikasi guru penting diperhatikan dalam upaya pembangunan pendidikan agama yang berorientasi perdamaian dan nirkekerasan. Karena sadar atau tidak, penyebaran paham intoleran dan kekerasan daapt melalui melalui proses pengajaran di kelas, dalam artian melalui guru. Apabila seorang guru mempunyai paradigma pemahaman keberagamaan yang eksklusif dan radikal maka dia akan cenderung mengajarkan dan mengimplementasikan nilai-nilai keberagamaan tersebut terhadap siswa di sekolah. Namun sebaliknya, jika guru mempunyai paradigma pemahaman keberagamaan yang inklusif dan moderat maka Dia akan memiliki kecenderungan mengajarkan dan mengimplementasikan nilai-nilai keberagamaan tersebut terhadap siswa di sekolah ${ }^{35}$

Guru mempunyai peran penting dalam pendidikan agama karena dia merupakan salah satu target dari strategi pendidikan. berikut peran guru dalam menanamkan nilai-nilai keberagamaan yang inklusif dan moderat yaitu:

1. Seorang guru harus mampu untuk bersikap demokratis dalam artian segala tingkah lakunya, baik sikap maupun perkataannya tidak diskriminatif. Ketika guru agama menjelaskan tentang konflik agama yang melibatkan kaum Muslim dengan Kristen misalnya, maka dia harus mempu bersikap tidak memihak terhadap salah satu kelompok yang terlibat dalam pertikaian. Meskipun agama yang dianutnya sama dengan salah satu kelompok yang terlibat di dalamnya. Karena apabila seorang guru memihak terhadap salah satu kelompok agama yang terlibat dalam perang

${ }^{35}$ M. Ainul Yaqin, Pendidikan Multikultural; Cross-Cultural Understanding untuk Demokrasi (Yogyakarta: Filar Media, 2005), h. 61. 
tersebut, tentunya analisa dan penjelasannya akan menjadi sangat subyektif.

2. Guru seharusnya mempunyai kepedulian yang tinggi terhadap kejadian kejadian tertentu yang ada hubungannya dengan konflik agama. Contohnya ketika terjadi pengrusakan dan pembakaran tempat ibadah serta pengusiran kaum Ahmadiyah, maka guru harus mampu menjelaskan kasus tersebut dengan menggunakan paradigma pemahaman keberagamaan yang inklusif tanpa sedikitpun mengurangi eksistensi agama. Seorang guru harus mampu menjelaskan bahwa inti ajaran agama adalah menciptakan kedamaian dan kesejahteraan seluruh umat manusia. pengrusakan, pembakaran, pengeboman dan segala bentuk kekerasan adalah sesuatu yang dilarang agama karena kekerasan hanya akan menimbulkan masalah baru. Dialog dan musyawarah adalah cara-cara penyelesaian segala bentuk masalah yang sangat dianjurkan oleh agama. ${ }^{36}$

Selain itu kualifikasi guru atau tenaga pendidik dilihat juga harus dilihat dari aspek karakter . karena guru adalah figur teladan atau panutan para siswa, maka bagaimana guru bersikap dalam konteks pengembangan perdamaian harus diperhatikan. Karena itu, pendidikan agama haruslah dampu oleh guru maupun tokoh agama yang karkaternya juga mewujudkan perdamaian. Hal ini sangat berkaitan dengan budaya bangsa kita yang menempatkan orang dewasa (orang tua) sebagai orang yang menjadi panutan pertama. Maka tak heran jika dikatakan bahwa kualitas murid akan terlihat dengan kualitas gurunya.

6. Suasana lingkungan sekolah, masyarakat dan keluarga

Lingkuangan adalah sarana belajar. Karena itu suasana sekolah dan lingkungan masyarakat dan keluarga memegang peran yang sangat penting dalam pembinaan dan penananaman nilai kedamaian. Lingkungan ini adalah tempat anak didik dapat mengaplikasikan semua hal yang diterimanya. Kenyataan dalam lingkungan sekolah,

${ }^{36}$ M. Ainul Yaqin, Pendidikan Multikultural, h. 61-64. 
masyarakat dan keluarga yang berbeda dengan ajaran ideal yang dipelajarinya bisa jadi akan menimbulkan sikap apatis dalam diri anak didik.

Karena itu orang tua dan guru perlu memiliki kesamaan presepsi dalam medidik anak. Orang tua memegang peranan penting untuk menciptakan suasana lingkungan yang baik pada anak. Lingkungan yang lebih majemuk juga dapat memberikan ruang belajar yang lebih baik bagi seorang anak. Berteman dan beraktivitas dengan teman-temannya yang berbeda suku, ras dan agama akan memberikan anak atau peserta didik sarana untuk mengaplikasikan sendiri nilainilai perdamaian tersebut.

\section{Penutup}

Munculnya banyak kerusuhan dan kekerasan di Indonesia beberapa tahun terakhir yang melibatkan sentiment keagamaan pantut mengundang gugatan terhadap ketidakberdayaan pendidikan agama. Pendidikan lebih sekedar pengajaran, pengajaran dapat dikatakan sebagai proses transfer ilmu belaka, bukan transformasi nilai - nilai kepada anak didik dan pembentukan kepribadianya dengan segala aspek yang dicakupnya. Pengajaran lebih berorientasi pada pembentukan "tukang - tukang" atau para spesialis yang terkurung dalam ruang spesialisasinya yang sempit, yang karena itu, perhatian dan minatnya lebih bersifat teknis.

Pendidikan agama mempunyai tempat sangat penting dan strategis dalam pendidikan nasional. Karena pendidikan agama pada intinya bertujuan pada pendidikan akhlak.Namun ironisnya pendidikan agama justru acapkali menjadi bahan bakar konflik dan kekerasan atas nama agama. Oleh Karenanya sebagai sebuah cita Pendidikan agama diharapkan dapat menjadi standing transformasi untuk melahirkan peserta didik yang damai dan toleran dan tidak menjadi pemicu konflik dan kekerasan. 


\section{Daftar Pustaka}

Abdurrahman Assegaf, Pendidikan Tanpa Kekerasan:Tipologi,Kondisi,Kasus dan Konsep Yogyakarta: Tiara Wacana, 2004

Abdul Munir Mulkhan, Paradigma Intelektual Muslim; Pengantar Filsafat Pendidikan Islam dan Dakwah, Yogyakarta: Sippress, 1993

Abu Rokhmad, Radikalisme Islam dan Upaya Deradikalisasi Paham Radikal. Jurnal Walisongo, Vol. 20, No. 1, Mei 2012

Amin Abdullah, Agama dan Pembentukan Kepribadian Bangsa di Indonesia, https://aminabd.wordpress.com/2010/06/03/71/. Diakses 6 November 2018

Aunur rofiq, Tafsir Resolusi Konflik Malang: UIN Maliki Press, 2011

Burhanuddin Salam, Pengantar Pedagogik Dasar-dasar Ilmu Mendidik, Jakarta: PT. Rineka Cipta, 1996

Bashori A. Hakim dalam Badan Litbang dan Diklat Kementerian Agama, Pandangan Masyarakat Terhadap Tindak Kekerasan Atas Nama Agama, Jakarta : Maloho Jaya Abadi Press, 2010

Depertemen Pendidikan dan kebudayaan, Kamus Besar Bahasa Indonesia.http://kbbi.web.id/konflik

Departemen Agama, Pedoman Pembinaan Kerukunan Hidup Beragama: Pokok-Pokok Ajaran Agama Tentang Kerukunan Hidup Bersama, Jakarta: Departemen Agama, 1990 
Dean G. Pruitt \& Jeffrey Z. Rubin, Social Conflict: Escalation, Stalemate, and Settlement, terj. Teori Konflik Sosial, Yogyakarta: Pustaka Pelajar, 2004

Erik Lincoln dan Irfan Amalee, Peace Generation: 12 Nilai Perdamaian, Bandung: Penerbit Pelagi Mizan, 2006

Erik Lincoln dan Florence Farida, Peace Generation: 12 Nilai Perdamaian, edisi Kristen, Bandung: Penerbit satu-satu, 2011

Elly M. Setiadi dan Usman Kolip, Pengantar Sosiologi Pemahaman Fakta dan Gejala Permasalahan Sosial: Teori, Aplikasi, dan Pemecahannya, Jakarta : Kencana, 2011

George R. Knight, Filsafat Pendidikan, Yogyakarta: Gama Media, 2007

Hassan Hanafi, Agama, Kekerasan dan Islam Kontemporer, terj. Ahmad Najib, Yogyakarta: Jemdela, 2001

H. H. Gerth \& C. Wright Mills, From Marx Weber: Essays in Sociology, London: Routledge, 1991

James S. Page, Peace Education: Exploring Ethical and Philosophical Foundations, Chapter 1, Charlotte: Information Age Publishing, 2008 dan Page, James S. 'Chapter 9: The United Nations and Peace Education'. dalam : Monisha Bajaj ed. Encyclopedia of Peace Education. Charlotte: Information Age Publishing, 2008,

J. Dwi Narwoko dan Bagong Suyanto, Sosiologi Teks Pengantar dan Terapan, Jakarta: Kencana, 2005

Johan Galtung, Kekerasan Budaya, dalam Thomas Santoso ed., Teoriteori kekerasan, Jakarta: Ghalia Indonesia \& Universitas Kristen Petra, 2002 
Kamrani Buseri, Antologi Pendidikan Islam dan Dakwah: Pemikiran Teoritis Praktis Kontemporer, Yogyakarta: UII Press, 2003

M. Ainul Yaqin, Pendidikan Multikultural; Cross-Cultural Understanding untuk Demokrasi Yogyakarta: Filar Media, 2005

Mohammed Abu Nimer dan Ilham Nasser, Building Peace Education In The Islamic Educational Context, International Review of Education, April 2017, Volume 63, Issue 2. DOI: 10.1007/s11159017-9632-7

Mohammad Takdir Ilahi, Nasionalisme dalam Bingkai Pluralitas Bangsa: Paradigma Pembangunan dan Kemandirian Bangsa, Yogyakarta: Ar-Ruzz Media, 2012

Pusat Pengkajian Islam dan Masysrakat UIN Jakarta, Policy Brief; Tanggung Jawab Negara dalam Pendidikan Agama Islam, September 2016

Robert lawang, Buku Materi Pokok Pengantar Sosiologi, Jakarta:universitas terbuka,1994

Rizal Panggabean dan Ihsan Ali Fauzi, Merawat Kebersamaan;Polisi,Kebebbasan Beragama dan Perdamaian Jakarta :Yayasan Abad Demokrasi 2011

Soerjono Soekanto, Sosiologi Suatu Pengantar Jakarta: Rajawali Pers, 1992

Sumanto al Qurtuby, Pluralisme, Dialog dan Piecbuilding berbasis agama di Indonesia, dalam Elza Peldi Taher ed, Merayakan kebebasan beragama; bunga Rampai menyambut 70 tahun Djohan Effendi, Jakarta Yayasan Abad demokrasi, 2011 
, Jihad Melawan Ekstremis Agama Membangkitkan Islam Progresif, Jakarta: PT. Borobudur Indonesia Publishing, 2009

Syaiful Sagala, Manajemen Stratejik dalam Peningkatan Mutu Pendidikan Bandung: Alfabeta, 2007

Tim PPK,Modul Pelatihan Program Penguiatan Karakter, Jakarta: Kemendikbud, 2017

Winardi, Manajemen Konflik: Konflik Perubahan dan Pengembangan Bandung: Mandar Maju, 1994

Zakiyuddi Baidhawy, Building Harmony and Peace through Multiculturalist Theology-based Religious Education: an Alternative for Contemporary Indonesia, British Journal of Religious Education, Volume 29, Number 1 January 2007, h. 1530. DOI: $10.1080 / 01416200601037478$ 